\title{
Management of Non-Healing Ulcer with topical application of Marham-i- 'Asal - A case study
}

\author{
Mohd Afsahul Kalam, ${ }^{1 *}$ Mohd Tauseef Alam, ${ }^{2}$ Fouzia Farooq ${ }^{2}$
}

${ }^{1}$ Research officer Unani \& Lecturer, Department of Ilmul Advia (Unani Pharmacology), Regional Research Institute of Unani Medicine, Srinagar, 190006

${ }^{2}$ PG Scholars, Department of Moalajat (Medicine), Regional Research Institute of Unani Medicine, Kashmir University, Srinagar. 190006

\begin{abstract}
:
The wounds which fail to progress through a timely sequence of repair or that proceed through the wound healing process without restoring anatomic and functional integrity are referred to as chronic non-healing wounds. This study was conducted on a 50-year old male patient with a painful nonhealing ulcer on the medial malleolus of the left lower limb caused by the use of hot water bag during harsh winter in Srinagar. The size of the wound was $2 \times 2 \mathrm{~cm}$ on assessing the wound profile. The wound was treated with the application of an ointment made with the combination of powder of Astragalus sarcocolla and Honey in equal amounts. The ointment was applied twice a day on the wound for 20 days. After 7 days of daily application, there was a considerable reduction in the size of wound and significant improvement in other symptoms like pain and tenderness. The ulcer was completely healed in a time period of 21 days. The present case reports that, the ointment prepared with Astragalus sarcocolla and Honey is a cost effective treatment for chronic non-healing wound.
\end{abstract}

Key words: Astragalus sarcocolla, Honey, Marham-i- 'Asal, Non-healing ulcer, Unani medicine.

Received: 16.04.2021 Revised: 04.05.2021 Accepted: 10.06.2021 Published: 28.06.2021

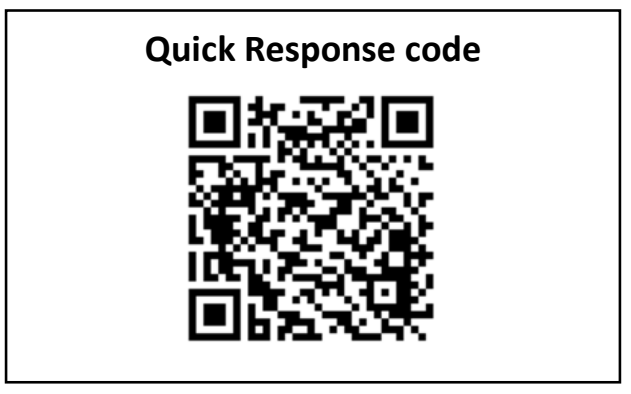

*CORRESPONDING AUTHOR:

Dr. Mohd Afsahul Kalam,

Research Officer Unani \& Lecturer, Department of Ilmul Advia, Regional Research Institute of Unani

Medicine, Srinagar, 190006.

E-mail : afsahnium@gmail.com 


\section{Introduction:}

Wound is a breach in the normal tissue continuum, resulting in a variety of cellular and molecular sequelae. The term generally applies to more superficial forms of tissue damage, whereas the term injury is used for damage to deeper structures. ${ }^{[1]}$ When the process of healing does not take its normal course, the problems of under healing or over healing occur. The wounds which fail to progress through a timely sequence of repair over a period of three months or the wounds that proceed through the wound healing process without restoring anatomical and functional integrity are referred to as chronic non-healing wounds. ${ }^{[2]}$

In Unani System of Medicine Jarahat (wound) is defined as breach in the continuity of the soft tissue that after healing leaves Khatam (scar) for life. ${ }^{[3]}$ This resembles closely with the modern definition (i.e., the scar is made up of a cellular connective tissue devoid of inflammatory infiltrate, covered by intact epidermis. The drug or agent, that heals or dries the wound, used in the Unani system of medicine are entitled under the terms of Mudammil-i-Quruh and Mumbit-i-Leham, Qabiz and Mujaffif-i-Quruh. ${ }^{[4-5]}$ For the management of the wounds, animal products, minerals and plants and their extracts having styptic property in nature, have immense potential of wound healing e.g. Aloe barbadensis L., Commiphora myrrha Engl, Quercus infectoria Olive, Dracaena cinnabari Ball, Dorema ammoniacum, allum, Pinus longifolia, Shorea robusta, hydrated magnesium Silicate, honey, Boswellia serrata Roxb, Astragalus sarcacola Dymoc, Zinc Oxide. ${ }^{[6-8]}$ Over the years many remedies have been used to facilitate and promote normal wound healing process. There are a number of ointments (Marham) having wound healing property like Marham-i-Ushaq, Marham-iMisri, Marham-i-Safeda Kafoori, Marham-i'Asal etc. which are mentioned in classical
Unani literature. Marham-i-'Asal prepared with Asal (honey) and Anzaroot (Astragalus sarcocolla) gum resin, has been selected for wound healing property in the management of a chronic non-healing wound, caused by excess use of hot water bag during harsh winter in Srinagar, Kashmir. ${ }^{[9]}$

\section{Case History:}

A 50-year old male patient was approached in OPD, RRIUM, Srinagar, in the month of July 2020 with the chief complaint of painful nonhealing ulcer on the medial malleolar region of left lower limb from 5 months. According to the history given by the patient, during the harsh 40-day winter period of Kashmir, starting from December $21^{\text {st }}$ to January $31^{\text {st }}$, he had suddenly developed a bulla in the medial malleolar region because of the excessive use of a hot water bag (commonly used in this region to combat cold) which subsequently ruptured and resulted in the formation of an open wound. The ulcer was associated with pain which increased with the movement of ankle joint and on walking, thereby affecting the day to day activities of the patient. Before visiting the OPD with chronic non-healing ulcer, the patient had received various topical and oral antibiotics for above five months with no satisfactory result. There was no history of discharge from the wound. The patient had no history of hypertension, metabolic disease, tuberculosis etc. The past medical and surgical history was non-significant. The patient had no relevant family history of any kind of chronic ulcer.

\section{Examination of patient:}

On examination general condition of the patient was stable. Vitals were within normal limit, with BP: $124 / 80 \mathrm{mmHg}$, heart rate: $76 / \mathrm{min}$, respiratory rate; $18 / \mathrm{min}$ and no abnormality was detected through systemic examination. The local examination of the ulcer was done to elucidate the wound profile (Table-1.) Before starting the procedure 
patient underwent through some precautionary lab investigations like complete blood count (CBC), erythrocyte sedimentation rate (ESR), fasting blood sugar (FBS), Blood Urea, Serum Creatinine (Table- 2.)

Table-1: Wound profile:

\begin{tabular}{|l|l|}
\hline Characteristic & Findings \\
\hline Inspection & Medial malleolar region of left lower limb. \\
\hline Site & One \\
\hline No. of wounds & $2 \times 2 \mathrm{~cm}^{2}$ \\
\hline Size of wound(measured using scale) & Sloping \\
\hline Edges & Yellowish slough with unhealthy granulation tissue. \\
\hline Floor & Discharge absent \\
\hline Discharge & Normal \\
\hline Surroundings & \multicolumn{2}{|l|}{} \\
\hline Palpation & Not raised \\
\hline Local temperature & Present \\
\hline Tenderness & Normal \\
\hline Margins & Malleolus \\
\hline Base & Absent \\
\hline Bleeding on touch & $\begin{array}{l}\text { Pulsations present (posterior tibial artery pulse and dorsalis } \\
\text { pedis artery pulse) }\end{array}$ \\
\hline Pulsations & 1.2 \\
\hline Ankle-Brachial Index &
\end{tabular}

Table-2: Laboratory Investigations:

\begin{tabular}{|l|l|l|}
\hline \multicolumn{1}{|c|}{ Laboratory Test } & Observed Value & Reference range \\
\hline WBC & 4.4 & $4.8-10.8 \mathrm{KmcL}$ \\
\hline RBC & 4.58 & $4.7-6.1 \mathrm{M} / \mathrm{mcL}$ \\
\hline HgB & 14.6 & $14-18 \mathrm{~g} / \mathrm{dL}$ \\
\hline HCT & 44.5 & $42-52 \%$ \\
\hline MCV & 96 & $80-100 \mathrm{fL}$ \\
\hline MCH & 29.8 & $27.0-32.0 \mathrm{pg}$ \\
\hline MCHC & 33.5 & $32.0-36.0 \mathrm{~g} / \mathrm{dl}$ \\
\hline RDW & 12.6 & $11.5-14.5 \%$ \\
\hline PLT & 160 & $150-450 \mathrm{~K} / \mathrm{mcL}$ \\
\hline Neutrophil & 50 & $33-73 \%$ \\
\hline Lymphocytes & 27.5 & $13-52 \%$ \\
\hline Monocyte & 8 & $0-10 \%$ \\
\hline Eosinophil & 2 & $0-5 \%$ \\
\hline Basophil & 1 & $0-2 \%$ \\
\hline ESR & 21 & $0-22 \mathrm{~mm} / \mathrm{hr}$ \\
\hline FBS & 89 & $70-110 \mathrm{mg} / \mathrm{dL}$ \\
\hline
\end{tabular}


INTERNATIONAL JOURNAL OF AYUSH CASE REPORTS (IJA-CARE)

\begin{tabular}{|l|l|l|}
\hline Blood urea & 15.6 & $10-20 \mathrm{mg} / \mathrm{dL}$ \\
\hline Serum creatinine & 0.8 & $0.6-1.2 \mathrm{mg} / \mathrm{dL}$ \\
\hline Sr. cholesterol & 188 & $<200 \mathrm{mg} / \mathrm{dL}$ \\
\hline Sr. Triglycerides & 139 & $<150 \mathrm{mg} / \mathrm{dL}$ \\
\hline Sr. HDL & 45 & $40 \mathrm{mg} / \mathrm{dL}$ or higher \\
\hline Sr. LDL & 90 & $<100 \mathrm{mg} / \mathrm{dL}$ \\
\hline
\end{tabular}

\section{Therapeutic intervention:}

\section{Collection of materials:}

$50 \mathrm{gm}$ Anzaroot (Astragalus sarcocolla) was obtained from Unani Medicine Market in Srinagar and honey (50gm) was obtained from an apiculture vender.

\section{Method of Preparation:}

The $50 \mathrm{ml}$ honey was boiled after adding some water and filtered. The $50 \mathrm{gm}$ of Anzaroot (Astragalus sarcocolla) was pulverized into a fine powder and then mixed with filtered honey to make an ointment like consistency. ${ }^{9}$

\section{Procedure:}

The treatment was commenced on the first visit to the OPD. No oral medications were prescribed. The wound was cleaned by normal saline, followed by application of the mixture of 'Asal and Anzaroot on the wound using a sterile applicator, which was then covered with thin sterile gauze pad and patient was advised to do the same twice a day, in the morning and evening for 20 days. On every follow-up visit, which was done after every 7 days, a photograph of the wound was taken. (Fig- 1.)

\section{Result and Discussion:}

In this study Honey and Anzaroot was used to prepare ointment (Marham-i-'Asal). Honey has been used since ancient times as an agent that hastens wound healing process due to its potent antimicrobial activity. It also has antioxidant, anti-inflammatory properties. Besides this, the viscosity of honey provides a protective barrier to prevent infection. ${ }^{[10]}$ There are many report of honey being very effective as dressing of wounds, burns, skin ulcers and inflammations. The anti-bacterial properties of honey speeds up the growth of new tissue to heal the wound. ${ }^{[11]}$ Anzaroot is a reddish yellow, bitter gum resin, obtained from Astragalus sarcocolla Dymok, which has desiccant, wound healing and antiinflammatory properties and is used to treat wounds and inflammations. ${ }^{[6]}$ A study conducted on the Astragalus sarcocolla also demonstrated the antimicrobial activity against Gram-positive and Gram-negative bacteria. ${ }^{[12]}$ There was a visible effect of this ointment (Marham-i-'Asal) on the wound healing process. After 7 days of treatment, there was a considerable reduction in the size of the wound and significant improvement in the other symptoms like pain and tenderness. The wound was completely healed by the antibacterial and wound healing properties of honey and Anzaroot in a time period of 21 days without leaving any scar. 


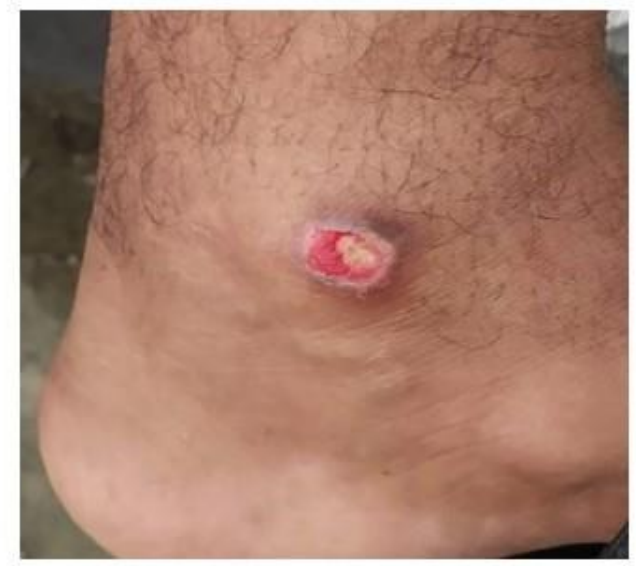

BASE LINE (0 day)

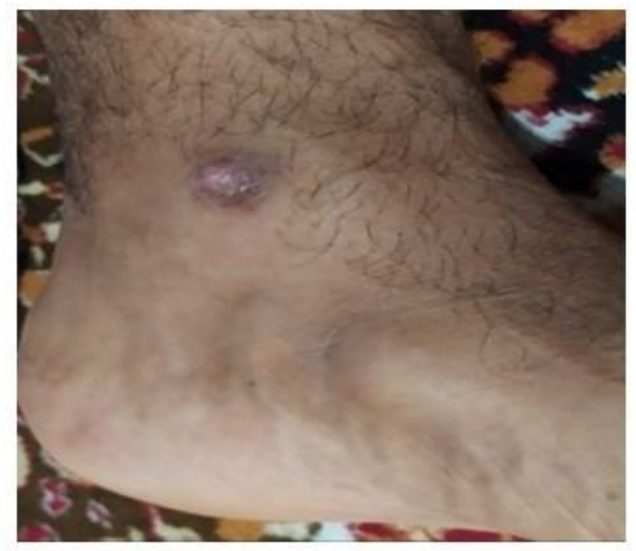

$2^{\mathrm{ND}}$ FOLLOW UP (after 14 days)

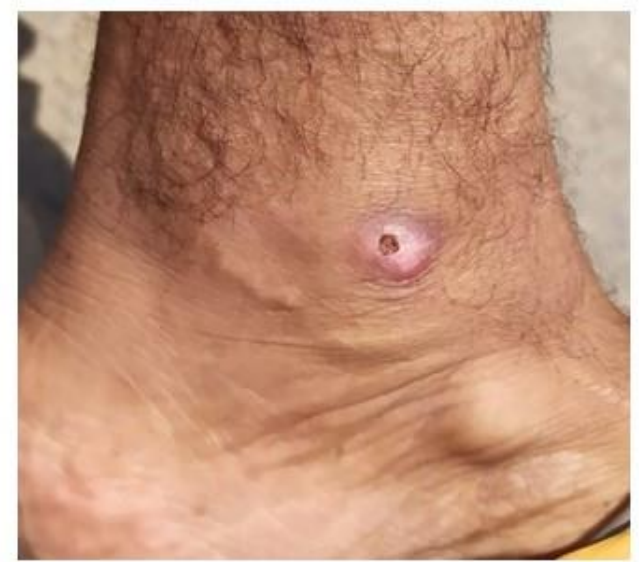

$1^{\text {STFOLLOW UP (after } 7 \text { days) }}$

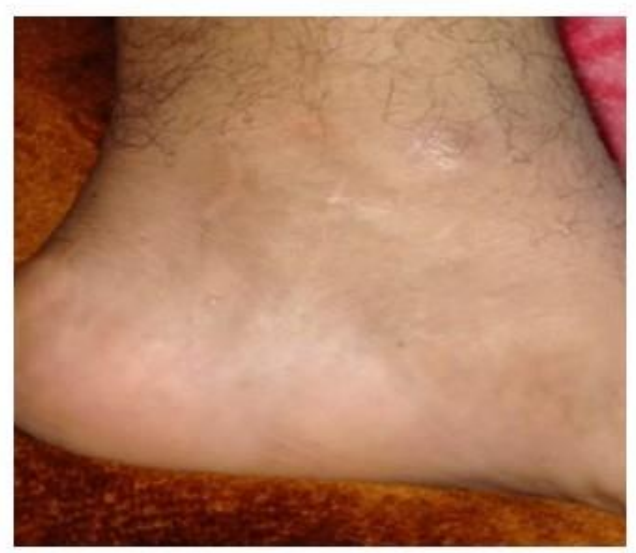

$3^{\text {rd }}$ FOLLOW UP (after 21 days)

Fig-1: Showing chronic Non-healing ulcer and its recovery at different stages of treatment

\section{Conclusion:}

Medicinal plants are being used since times immemorial, as a first line of treatment for trauma, infection, injuries etc. This case study demonstrates successful treatment of a nonhealing wound with the topical ointment made with Astragalus sarcocolla and Honey without any adverse reactions. The results revealed promising wound healing property of Astragalus sarcocolla and Honey because of their potent antimicrobial activity. This might prove to be an efficacious wound healing ointment in case of chronic wounds of different genesis. Further case studies / trails need to be done in future to elaborate the activity of this ointment.

\section{Acknowledgement:}

Authors duly acknowledge the Assistant Director In charge, clinical and non-clinical staff of RRIUM, Srinagar, for their continued cooperation throughout the study.

\section{Consent of the patient:}

The consent of the patient was taken on a written consent form, after duly explaining the procedure of the study to the patient.

\section{Limitation of Study:}

The study was not carried out in an inpatient setting, moreover the results cannot be generalised. 


\section{References:}

1. MannV, Russell RCG and Norman S, Bailey and Love's Short Practice of Surgery. ELBS with Chapman and Hall, London. 1998,8-16.

2. https://www.facs.org/-/media/ files/ education/core-curriculum/ nonhealing wounds.ashx. (Last accessed on 13/04/2021).

3. Arzani A, Akseerul Quloob (Tarjama Mufarrehul Quloob). Idara Kitabus Shifa, New Delhi.2002, 218.

4. Ghani N,Khazainul Advia. Idara Kitabus Shifa, New Delhi.2011, 269-271.

5. Abdul Hakim, Bustanul Mufradat. Idara Kitabus Shifa, New Delhi.2011,74, 221

6. Ibn Sina, Al-Qanoon Fi'lTibb: Tibb-iUnani Ka Encyclopaedia. Aijaz Publishing House, New Delhi. 2010, Vol-2,p- 273, 277.

7. Razi AMBZ, Kitabul Mansoori (Urdu translation). Central Council for Research in Unani Medicine, New Delhi.1991, 259.

8. Azam MK, Muheet-i-Azam. Maktaba Nizam, Kanpur. Vol-IV, 1867, 9-10.

9. Anonymous. National Formulary of Unani Medicine. Central Council for Research in Unani Medicine, New Delhi. 2006, Vol IV, p- 120
10. Mohammed Aman M. Teshome T, and Detamo J. Antibacterial Activity of Honey against Methicillin-Resistant Staphylococcus aureus: A LaboratoryBased, Experimental Study. International Journal of Microbiology 2019, 1-9

11. Lusby PE, Coombes A, Wilkinson JM. Honey: A potent agent for wound healing. J Wound Ostomy Continence Nurs 2009; 29: 295-300

12. Ibtisam MA. Antimicrobial Activity and Phytochemical Screening of Sarcocolla Gum Resin. Pakistan Journal of Biological Sciences. Pak. J. Biol. Sci. 2017; 20 (11): 571-576

Conflict of interest: Author declares that there is no conflict of interest.

Guarantor: Corresponding author is guarantor of this article and its contents.

\section{Source of support: None}

\section{How to cite this article:}

Kalam MA, Alam MT, Farooq F. Management of Non-Healing Ulcer with topical application of Marham-i-'Asal Ointment - A case study. Int. J. AYUSH CaRe. 2021; 5(2):78-83. 